\title{
MELIHAT LEMBAGA KEUANGAN ANJAK PIUTANG DIBANDINGKAN PERBANKAN DILIHAT DARI ASPEK HUKUM ?
}

\author{
Rani Eka Diansari ${ }^{1}$ \\ Lulu Amalia Nusron ${ }^{2}$ \\ ${ }^{1}$ Fakultas Bisnis, Universitas PGRI Yogyakarta, Indonesia \\ ranieka@upy.ac.id
}

\begin{abstract}
This study aims to determine whether there are differences in banking and factoring institutions viewed from the legal aspect. This study uses secondary data obtained from the results of previous studies. This research belongs to the type of library research (library research), which is looking for data from various kinds of library information including documents, newspapers, magazines, books, scientific journals, and encyclopedias. This research uses descriptive analysis, philosophical and pedagogical approaches. The results of the analysis of this study are that there are differences in legal aspects seen from the actors, regulations, mechanisms, ways of solving problems, etc. in banks and factoring institutions.
\end{abstract}

Keywords: factoring, banking, legal aspects.

\section{PENDAHULUAN}

Di era digital seperti saat ini, industry menghadapi suatu kondisi, Menghadapi era globalisasi dimana persaingan bisnis dan industri semakin ketat, sehingga memaksa pelaku usaha selalu berusaha untuk melakukan bermacam inovasi produk maupun sistem penjualan untuk dapat meningkatkan omset perusahaan. Berbagai macam upaya dilakukan untuk dapat menaikkan keuntungan dan omset penjualan, salah satu diantaranya adalah memperluas pasar serta memenuhi permintaan dan kebutuhan pelanggan. Salah satu usaha yang dilakukan oleh pelaku usaha dalam rangka memenuhi permintaan pelanggan adalah dengan mempermudah syarat dan cara pembayaran produk yang diperjual belikan. Mempermudah tata cara pembayaran salah satu diantaranya adalah pembayaran secara bertahap atau tempo. Cara pembayaran kredit atau tempo memang dinilai efektif untuk meningkatkan omset penjualan suatu produk, akan tetapi cara tersebut bukan tidak beresiko. Terdapat beberapa resiko yang akan diamani oleh perusahaan ketika memilih syarat pembayaran tempo atau kredit tanpa melibatkan lembaga keuangan seperti Bank, hal tersebut dikarenakan tidak adanya barang jaminan yang menjamin kelancaran pembayaran pelanggan. Selain itu penjualan kredit atau tempo juga akan mengganggu cashflow jika kondisi kas perusahaan tidak dalam kondisi yang surplus. Jika resiko penjualan kredit itu terjadi, dan piutang gagal tertagih maka akan mendatangkan masalah pendanaan yang serius bagi 
perusahaan. Untuk mengatasi segala permasalahan tersebut sebenarnya perusahaan bisa memilih untuk menjual atau mengalihkan faktur piutang yang dimiliki ke lembaga anjak piutang. Perusahaan Anjak piutang adalah sebuah perusahaan yang berfungsi mengambil alih piutang yang terjadi atas transaksi jual beli agar tidak menimbulkan permasalahan serius pada aliran kas perusahaan. Dengan adanya perusahaan pembiayaan yang memiliki konsep memberikan jasa pengalihan piutang dengan konsep anjak piutang (factoring), maka akan mempermudah perusahaan dalam menyelesaikan permasalahan piutangnya yang belum dapat tertagih dan dapat terhindar dari risiko yang tidak diinginkan seperti ingkar janji dari pihak lain (Aprianto, 2017).

Perusahaan anjak piutang atau factoring dikenal di Indonesia pada akhir tahun 1988 yaitu sejak berlakunya Keputusan Presiden Nomor 61 Tahun 1988 tentang Ketentuan dan Tata Cara Pelaksanaan Lembaga Pembiayaan. Anjak Piutang (factoring) menurut Keputusan Presiden Nomor 61 Tahun 1988 merupakan pembiayaan dalam bentuk dan/atau pengalihan serta pengurusan piutang atau tagihan jangka pendek suatu perusahaan dari transaksi perdagangan dalam dan luar negeri (Kasmir, 2014:269). Berdasarkan konsep anjak piutang, sebenarnya keberadaan perusahaan anjak piutang ini sangat menguntungkan untuk perusahaan khususnya perusahaan dagang, akan tetapi jika melihat data di Indonesia masih sangat sedikit sekali keberadaan perusahaan anjak piutang, bukti tersebut bisa kita lihat di Bursa Efek Indonesia, masing kurang dari 100 perusahaan anjak piutang yang listed di bursa saham. Hal tersebut menunjukkan bahwa di Indonesia perusahaan Anjak Piutang sangat kurang berkembang. Dengan kondisi tersebut penulis tertarik untuk melihat bagaimana Lembaga Keuangan Anjak Piutang dibandingkan Perbankan dari aspek Hukum.

\section{KAJIAN TEORI DAN} PENGEMBANGAN HIPOTESIS

\section{ANJAK PIUTANG (Factoring)}

Anjak piutang (factoring) adalah salah satu dari sekian banyak lembaga keuangan yang merupakan lembaga pembiayaan berdasarkan Keputusan Presiden Nomor 61 Tahun 1988 tentang Lembaga Pembiayaan, yang ditindak lanjuti dengan Keputusan Menteri Keuangan Republik Indonesia Nomor 1251/KMK.013/1988 tentang Ketentuan dan Tata Cara Pelaksanaan Lembaga Pembiayaan.

Menurut Kasmir (2014) perusahaan anjak piutang merupakan perusahaan yang kegiatannya melakukan penagihan atau pembelian, atau pengambilalihan atau pengelolaan utang piutang suatu 
perusahaan dengan imbalan atau pembayaran tertentu milik perusahaan.

\section{Kegiatan Anjak Piutang}

Kegiatan perusahaan anjak piutang di Indonesia diatur dalam Surat Keputusan Menteri Keuangan Nomor 1251/KMK/.013/1988 tanggal 20 Desember 1988. Berdasarkan Surat Keputusan Menteri Keuangan tersebut dapat dijabarkan bahwa kegiatan perusahaan anjak piutang meliputi:

1) Pengambilalihan tagihan suatu perusahaan dengan fee tertentu;

2) Pembelian piutang perusahaan dalam suatu transaksi perdagangan dengan harga yang sesuai dengan kesepakatan;

3) Mengelola usaha penjualan kredit suatu perusahaan, artinya perusahaan anjak piutang dapat mengelola kegiatan administrasi kredit suatu perusahaan sesuai kesepakatan.

\section{Pihak Yang Terlibat}

Dalam kegiatan transaksi perusahaan anjak piutang terdapat tiga pihak yang saling berkepentingan. Tanpa keterlibatan ketiga pihak tersebut, maka perusahaan anjak piutang tidak akan berjalan sebagaimana mestinya.

Pihak - pihak yang terlibat dalam kegiatan transaksi anjak piutang meliputi:

1) Kreditor atau klien yang menyerahkan tagihannya kepada pihak anjak piutang untuk ditagih atau dikelola atau diambil alih dengan cara dikelola atau dibeli sesuai perjanjian dan kesepakatan yang telah dibuat.

2) Perusahaan anjak piutang (factoring), yaitu perusahaan yang akan mengambil alih atau mengelola piutang atau penjualan kredit debiturnya.

3) Debitur, yaitu nasabah yang mempunyai masalah (utang) kepada kreditor (klien).

\section{Fasilitas Yang Diberikan Kepada Klien}

Menurut Kasmir (2014) fasilitas yang diberikan perusahaan anjak piutang dalam penagihan atau pengelolaan kreditnya kepada klien dapat dilihat dari berbagai sisi sebagai berikut:

1) Berdasarkan Pemberitahuan

a) Disclosed

Yaitu fasilitas yang diberikan kepada perusahaan anjak piutang dalam penagihan piutangnya dengan sepengetahuan debitur.

b) Undisclosed

Merupakan fasilitas yang diberikan kepada perusahaan anjak piutang tanpa sepengetahuan debitur, kecuali jika ada pelanggaran terhadap kesepakatan yang telah dibuat dan atau oleh perusahaan anjak 
piutang mengandung suatu resiko.

2) Berdasarkan Tanggung Jawab

a) Withrecourse

Apabila debitur tidak mampu untuk melunasi segala kewajibannya, maka resiko kredit tersebut menjadi tanggung jawab pihak kreditor dan pihak anjak piutang mengembalikan tanggung jawab penagihannya.

b) Without recourse

Apabila semua resiko yang tidak terbayar dalam suatu penagihan piutang menjadi tanggung jawab pihak anjak piutang sepenuhnya dan bukan tanggung jawab kreditor.

3) Berdasarkan Pelanggan

a) Full service factoring

Merupakan perusahaan anjak piutang yang memberikan semua jenis fasilitas jasa anjak piutang baik dalam jasa pembiayaan maupun jasa nonpembiayaan, termasuk fasilitas untuk menanggung risiko terhadap kredit yang macet.

b) Resource factoring

Jasa yang diberikan oleh perusahaan anjak piutang meliputi hampir semua jasa anjak piutang kecuali proteksi terhadap risiko tidak terbayar tagihannya. Dalam hal ini risiko kredit tetap berada pada kreditor.

c) Bulk factoring

Jasa yang diberikan terhadap kreditor hanyalah fasilitas jasa pembiayaan dan pemberitahuan jatuh tempo pada debitur.

d) Maturity factoring

Dalam perusahaan jenis ini fasilitas yang diberikan kepada kreditor adalah perlindungan kredit yang meliputi pengurusan atas penjualan, penagihan dari debitur dan perlindungan atas piutang dan dalam jenis ini jasa yang diberikan adalah tanpa pembiayaan.

e) Invoice discounting

Pemberian fasilitas jasa hanyalah untuk yang berbentuk pembiayaan anjak piutang.

f) Undisclosed factoring

Dalam fasilitas ini perusahaan anjak piutang memberikan proteksi terhadap kemacetan pelunasan piutang sampai dengan persentase tertentu dari jumlah faktur yang telah disetujui.

g) Advance Payment

Yaitu transaksi pengalihan

piutang di mana 
pembayarannya dilakukan pada saat jatuh tempo dan besarnya sekitar $80 \%$ dari nilai faktur.

4) Berdasarkan Wilayah

a) Domestic Factoring

Merupakan perusahaan anjak piutang yang hanya beroperasi di wilayah Indoenesia.

b) International Factoring Merupakan kegiatan anjak piutang yang kegiatannya dapat dilakukan antarnegara seperti pembiayaan fasilitas ekspor impor.

\section{Jasa Yang Diberikan}

Secara umum perusahaan anjak piutang mempunyai dua macam jasa yang dapat ditawarkan kepada masyarakat. Adapun jasa-jasa yang dilakukan perusahaan anjak piutang adalah sebagai berikut:

1) Jasa Pembiayaan (Financing Service)

Dalam hal jasa pembiayaan, perusahaan anjak piutang melakukan pembayaran dimuka kepada kreditor yang besarnya tergantung dari kesepakatan kedua belah pihak. Kontrak dalam perjanjian dapat dibuat berdasarkan withrecourse atau dengan without recourse. Besarnya pembiayaan yang dilakukan sekitar $60 \%-80 \%$ dari total piutang setelah dilakukan kontrak dan penyerahan bukti-bukti penjualan.
2) Jasa Non Pembiayaan

Dalam jasa non pembiayaan kegiatan yang dilakukan meliputi pemberian jasa pengelolaan administrasi kredit. Kegiatan jasa ini antara lain:
a. analisis kelayakan suatu kredit;
b. melakukan administrasi kredit;
c. pengawasan terhadap kredit termasuk pengendaliannya;
d. perlindungan terhadap suatu risiko kredit.

\section{Keuntungan Anjak Piutang}

Dalam kegiatan anjak piutang akan memberikan atau memperoleh keuntungan bagi masing-masing pihak yang terlibat, baik perusahaan anjak piutang, kreditor maupun debitur.

Keuntungan yang diperoleh masingmasing pihak adalah sebagai berikut:

1) Bagi Perusahaan Anjak Piutang

a) Memperoleh keuntungan berupa fee dan biaya administrasi

b) Membantu menyelesaikan pertikaian di antara kreditor dan debitur.

c) Membantu manajemen pihak kreditor dalam penyelenggaraan kredit.

2) Bagi Kreditor (Klien)

a) Mengurangi risiko kerugian dengan tertagihnya piutangnya

b) Memperbaiki sistem administrasi yang semrawut 
c) Memperlancar kegiatan usaha

d) Dengan ditagihnya piutang oleh perusahaan anjak piutang, kreditor dapat berkonsentrasi ke usaha lainnya.

3) Bagi Debitur

Memberikan motivasi kepada debitur untuk segera membayar secepatnya, karena ada rasa malu sehingga berusaha untuk segera membayar dengan berbagai cara.

\section{PERBANKAN}

Secara umum dapat dikatakan, bahwa Bank sebagai lembaga keuangan menjadi pihak perantara bagi sektor rumah tangga dan sektor industri, khususnya di dalam menyerap dana dari sektor rumah tangga dalam bentuk tabungan dan menyalurkannya kepada sektor industri sebagai kredit investasi. Meskipun dalam prakteknya penyerapan dan penyaluran dana itu sendiri dapat terjadi baik di dan untuk sektor rumah tangga maupun sektor industri. Menurut UU Nomor 10 Tahun 1998 yang disyahkan tanggal 10 November 1998 tentang Perbankan, yang dimaksud dengan bank adalah badan usaha yang menghimpun dana dari masyarakat dalam bentuk simpanan dan menyalurkannya kepada masyarakat dalam bentuk kredit dan atau bentukbentuk lainnya dalam rangka meningkatkan taraf hidup rakyat banyak. Dari pengertian di atas dapat dijelaskan secara lebih luas lagi bahwa bank merupakan perusahaan yang bergerak dalam bidang keuangan, artinya aktivitas perbankan selalu berkaitan dalam bidang keuangan (Wiwoho, 2014).

\section{a. Kegiatan yang dilakukan}

Ibrahim (2004) dalam Regar dkk (2016) menyatakan pada dasarnya bank mempunyai fungsi mentransfer dana-dana (leonable funds) dari penabung atau unit surplus (lenders) kepada peminjam (borrowers) atau unit deficit. Aktivitas perbankanyang pertama adalah menghimpun dana dari masyarakat luas yang dikenal dalam dunia perbankan istilah funding. Pengertian menghimpun dana yang dimaksud adalah mengumpulkan atau mencari dana dengan cara membeli dari masyarakat luas. Pembelian dana dari masyarakat ini dilakukan oleh bank dengan cara memasang berbagai strategi agar masyarakat mau menanamkan dananya dalam bentuk simpanan. Setelah memperoleh dana dalam bentuk simpanan dari masyarakat, oleh perbankan dana tersebut diputar atau dijual kembali kepada masyarakat dalam bentuk pinjaman atau lebih dikenal dengan istilah kredit (lending). 


\section{b. Fungsi Bank}

Menurut Sigit Triandaru dan Totok

Budisantoso (2006:9), fungsi utama

bank adalah menghimpun dana dari masyarakat dan menyalurkannya kembali kepada masyarakat untuk berbagai tujuan atau sebagai financial intermediary. Secara lebih spesifik bank dapat berfungsi sebagai agent of trust, agent of development, dan agent of services.

\section{c. Sumber Dana Bank}

Pengertian sumber dana bank adalah usaha bank dalam menghimpun dana dari masyarakat(Kasmir, 2012 : 50). Dalam menghimpun dana tersebut, sudah tentu bank harus mengenal sumber-sumber dana yang terdapat di dalam berbagai lapisan masyarakat dengan bentuk yang berbeda-beda pula. Secara garis besar sumber dana bank dapat diperoleh dari:

1) Bank itu sendiri. Perolehan dana dari sumber bank itu sendiri (modal sendiri) maksudnya adalah dana yang diperoleh dari dalam bank. Adapun pencarian dana yang bersumber dari bank itu sendiri terdiri dari:

a) Setoran modal dari pemegang saham, yaitu merupakan modal dari para pemegang saham lama atau pemegang saham baru.

b) Cadangan laba, yaitu merupakan laba yang setiap tahun dicadangkan oleh bank dan sementara waktu belum digunakan.

c) Laba bank yang belum dibagi, merupakan laba tahun berjalan tapi belum dibagikan kepada para pemegang saham.

2) Masyarakat luas. Sumber dana ini merupakan sumber dana terpenting bagi kegiatan operasi bank dan merupakan ukuran keberhasilan bank jika mampu membiayai operasi sumber dana ini. Untuk memperoleh dana dari masyarakat luas bank dapat menggunakan tiga jenis simpanan (rekening). Sumber dana yang dimaksud adalah sebagai berikut:

a) Simpanan Giro

b) Simpanan Tabungan

c) Simpanan Deposito Pembagian jenis simpanan ke dalam beberapa jenis dimaksudkan agar para penyimpan mempunyai pilihan sesuai dengan tujuan masingmasing. 
3) Dana yang bersumber dari lembaga lain. Merupakan tambahan jika bank mengalami kesulitan dalam pencarian sumber dana dari bank itu sendiri dan masyarakat luas. Perolehan dana dari sumber ini antara lain dapat diperoleh dari:

a) Bantuan Likuiditas Bank Indonesia (BLBI), merupakan dana yang diberikan Bank Indonesia kepada bank-bank yang mengalami kesulitan likuiditasnya.

b) Pinjaman antar bank (Call Money). Biasanya pinjaman ini diberikan kepada bankbank yang mengalami kalah kliring di dalam lembaga kliring dan tidak mampu untuk membayar kekalahannya.

c) Pinjaman dari bank-bank luar negeri, merupakan pinjaman yang diperoleh perbankan dari pihak luar negeri.

d) Surat Berharaga Pasar Uang (SBPU), dalam hal ini pihak perbankan menerbitkan SBPU kemudian diperjualbelikan kepada pihak yang berminat, baik perusahaan keuangan maupun non keuangan.

\section{METODE PENELITIAN}

\section{Metode Penentuan Subjek}

Penelitian ini merupakan penelitian yang berupa penelitan kepustakaan (library research), karena serangkaian data yang dicantumkan dalam penelitian ini diperoleh dengan cara metode pengumpulan data pustaka dengan menggali berbagai macam informasi informasi kepustakaan (buku buku literasi, ensiklopedi, jurnal ilmiah, koran, majalah, dan dokumen dokumen yang terkait dengan undang-undang ata aspek hukum lembaga keuangan anjak piutang dan perbankan). Fokus penelitian ini adalah menemukan berbagai teori, hukum, dalil, prinsip, atau gagasan yang digunakan untuk menganalisis dan memecahkan pertanyaan penelitian yang dirumuskan.

\section{HASIL PENELITIAN DAN}

\section{PEMBAHASAN}

\section{Penjabaran Lembaga Keuangan Bank}

Sektor jasa keuangan atau disebut SJK mengalami banyak perkembangan pada regulasi atau secara hukum yang ditunjukkan dari adanya perubahan otoritas yang melakukan pengawasan SJK. Jika sebelumnya pengawasan SJK dilakukan oleh Bapepam-LK, kini tugas tersebut beralih kepada Otoritas Jasa Keuangan (OJK). Pengawas oleh OJK dimulai ketika Undang-Undang Nomor 
21 Tahun 2011 tentang Otoritas Jasa Keuangan (UU OJK) diberlakukan. Oleh karena itu, Pengawasan sektor perbankan yang semula dilakukan oleh Bank Indonesia beralih ke OJK. Dengan demikian, saat ini ada dua lembaga yang bertugas mengotorisasi di sektor Jasa Keuangan, yaitu Bank Indonesia yang mengotorisasi kegiatan moneter dan OJK yang memiliki fungsi, tugas dan wewenang sektor jasa keuangan dengan mengatur, mengawasi, memeriksa, dan menyidik sebagaimana yang telah tertera dijelaskan dalam UU OJK. Dalam pasal 5 UU OJK tertera bahwa OJK harus menyelenggarakan sistem pengaturan dan pengawasan yang terintegrasi terhadap keseluruhan kegiatan di dalam SJK karena sektor keuangan semakin berkembang.

Salah satu kegiatan yang diatur yaitu mengenai perjanjian. Banyak perbankan dan pasar modal yang mengembangkan produk dan layanan yang memiliki hubungan terkait dengan perjanjian, khususnya perjanjian tidak bernama yang tunduk pada ketentuan Buku III KUHPerdata. Sektor jasa keuangan memerlukan penyesuaian dalam implementasi perjanjjian tersebut karena masih banyak SJK yang dipengaruhi oleh transaksi common law system. Penelitian ini membandingkan perjanjian yang ada dalam perbankan dan perusahaan anjak piutang. Dalam sektor perbankan, perjanjian trust dan transaksi hedging diatur dalam Peraturan Bank Indonesia. Sedangkan perjanjian anjak piutang mengacu pada UU Perbankan dan POJK dan diatur dalam UU tentang Lembaga Pembiayaan.

Sektor jasa keuangan dituntut mengikuti perkembangan perjanjian yang telah ada di Indonesia, dimana sebagian besar mengacu pada praktik sektor jasa keuangan global. Sebagai contoh, perbankan dan pasar modal memerlukan keberadaan perjanjian tidak bernama karena merupakan bagian dari prinsip dan standar keuangan global. Sistem hukum perjanjian tidak selalu diaplikasikan dengan sempurna meskipun secara hukum bersifat terbuka (Pasal 1319 KUHPerdata) dan menganut asas kebebasan berkontrak (Pasal 1338 ayat 1 KUHPerdata). Lastuti Abubakar (2009) memberikan contoh perjanjian trust di perbankan akan berhadapan dengan 2 ownership yang memiliki 1 aset tidak diatur dalam hukum benda Indonesia, sehingga hal ini perlu disesuaikan dalam klausul kontraknya. Hal yang sama juga terjadi pada transaksi derivatif di pasar modal yang memerlukan perluasan dalam konsep benda dan diatur secara tegas dan baik. Dalam hukum perdata perlu dilakukan pembaharuan dan hal ini menjadi suatu keharusan untuk mengikuti perkembangan transaksi dan produk di 


\section{FAKULTAS EKONOMI DAN BISNIS UNIVERSITAS WIRARAJA - MADURA}

SJK Indonesia. Model Niew Burgerlijk

Wetboek sudah lebih dulu yang mengantisiapasi perkembangan konsep benda pada perbankan dan pasar modal dan model ini perlu ditiru. Selain konsep benda, hukum SJK yang berkembang di Indonesia terdapat pada regulasi atau aturan yang berkaitan dengan layanan, produk, dan penyelesaian sengketa.

Kita ambil contoh perkembangan regulasi pada bidang perbankan. Regulasi perbankan yang dibentuk harus bisa memanfaatkan ASEAN Banking Integration Framework (ABIF) untuk memperluas jaringan dan pasar ke negara-negara ASEAN. Selain itu, bank juga perlu memperhatikan regulasi dalam menyalurkan dananya dalam bentuk perjanjian kredit. Pelaksanaan perjanjian ini harus dilakukan berdasarkan asas kehati-hatian sehingga bank maupun nasabah merasa saling diuntungkan ketika pemberian kredit akan dicairkan nantinya. Perjanjian kredit merupakan awal proses yang diterapkan perbankan sebagai kreditur dalam berupaya untuk mengembangkan dan memanfaatkan dana yang berasal dari masyarakat dan disebar lagi ke masyarakat yang membutuhkan sebagai debitur. Asas perjanjian kredit ini dilakukan berdasarkan sistem terbuka yang bersifat kebebasan dimana untuk membuatnya bisa di bawah tangan maupun di depan notaris (Idris, 2015).
Salah satu prinsip yang wajib diterapkan dalam aktivitas perbankan adalah prinsip kehati-hatian, baik secara kelembagaan, layanan, proses dan produk perbankan, terutama dalam menjalankan fungsi intermediary, yaitu penghimpunan dan penyaluran sebuah dana kepada pihak ketiga. Oleh sebab itu prinsip kehati-hatian bank haru difahami dengan baik dan tepat sesuai dengan maksud undang-undang, kepatuhan terhadap seluruh ketentuan perundangundangan.

Satu diantara prinsip kehati-hatian bank yang diatur dalam UU Perbankan dan UU Perbankan Syariah adalah dalam sebuah mekanisme pembiayaan syariah atau pemberian kredit, bank diwajibkan untuk yakin atas itikad baik dan kemampuan bank untuk melaksanakan kewajiban pembayaran utang serta melakukan analisa secara mendalam terkait kemampuan (capacity), watak (character), jaminan (collateral), permodalan (capital), serta prospek usaha (condition of economic) atau yang biasa dikenal dengan the $5 \mathrm{C}$ 's analysis of credit.

Penerapan prinsip kehati-hatian bank adalah wajib dan tidak serta merta tanggung jawab direksi, namun termasuk pejabat bank yang memiliki wewenang dan tanggung jawab mengenai segala hal yang berhubungan dengan usaha bank tersebut. Mematuhi 
segala ketentuan perundang-undangan dan ketentuan lain dalam UU Perbankan Syariah dan UU Perbankan, meliputi seluruh peraturan yang berkaitan dengan aktivitas perbankan, termasuk standar operasional perusahaan (SOP) yang dibuat oleh bank. Hal ini didasari oleh ketentua ndalam Pasal 8 ayat (2) dan Pasal 15 UU Perbankan, yang mewajibkan BPR dan Bank Umum memiliki pedoman SOP, sehingga SOP merupakan amanat undang-undang yang harus ditaati dan dijalankan.

\section{Penjabaran Lembaga Anjak Piutang}

Anjak piutang merupakan sebuah kegiatan dalam bentuk pembelian piutang dagang dalam jangka pendek suatu perusahaan termasuk pengurusan atas piutang tersebut. Keputusan Presiden Nomor 61 Tahun 1998 tentang lembaga pembiayaan dan keputusan menteri keuangan nomor 1251/KMK.013/1988 tentang ketentuan dan tata cara pelaksanaan lembaga pembiayaan. Kemudian diperbaharui dengan Peraturan Menteri Keuangan Nomor 84/PMK.012/2006 Tentang Perusahaan Pembiayaan. Meskipun secara khusus tidak diatur dalam $\mathrm{KUH}$ Perdata dan Perauran Perundangundangan lainya, namun dikarenakan terus berkembangnya kegiatan anak pihutang di Indonesia, maka terdapat 2 kelompok yang mendasari sebuah hukum bagi eksistensi anjak piutang, yaitu Dasar Hukum Substantif dan Dasar Hukum Administratif. Hukum substantif dibagi menjadi 2, yaitu Dasar hukum substantif Murni dan Dasar Hukum substantif Bertendensi Prosedural. Anjak piutang hadir memberikan alternatif dalam pemecahan masalah yang dialami oleh klien dan melalui anjak pihutang klien dapat menerima sumber pembiayaan / pendanaan dengan mudah dan cepat, serta dapat membantu mengatasi kesulitan dalam bidang pengelolaan kredit

\section{Segi Hukum Perdata}

Ada dua sumber hukum perdata yang mendasari kegiatan anjak piutang, yaitu asas kebebasan berkontrak dan perundang-undangan di bidang hukum perdata :

\section{1) Asas Kebebasan Berkontrak}

Hubungan hukum yang terjadi dalam kegiatan anjak piutang selalu dibuat secara tertulis (kontrak) sebagai dokumen hukum yang menjadi dasar kepastian hukum (legal certainty). Perjanjian anjak piutang ini dibuat berdasarkan atas asas kebebasan berkontrka yang memuat rumusan kehendak berupa hak dan kewajiban dari perusahaan anjak piutang sebagai pihak penerima pengalihan piutang, dank lien sebagai pihak yang mengalihkan piutang. 
Perjanjian anjak piutang (factoring agreement) merupakan dokumen hukum utama (main legal document) yang dibuat secara sah dengan memenuhi syarat-syarat sebagaimana ditetapkan dalam Pasal 1320 KUH Perdata. Akibat hukum perjanjian yang dibuat secara sah, maka akan berlaku sebagai undangundang bagi pihak-pihak, yaitu perusahaan anjak piutang dan klien (Pasal 1338 ayat (1) KUH Perdata). Konsekuensi yuridis selanjutnya, perjanjian tersebut harus dilaksanakan dengan itikad baik (in good faith) dan tidak dapat dibatalkan secara sepihak (unilateral unavoidable). Perjanjian anjak piutang berfungsi sebagai dokumen bukti yang sah bagi perusahaan anjak piutang dan klien.

2) Undang-Undang di Bidang Hukum Perdata

Perjanjian anjak piutang merupakan salah satu bentuk perjanjian khusus yang tunduk pada ketentuan Buku III dan Buku II KUH Perdata. Sumber hukum utama anjak piutang adalah ketentuan-ketentuan mengenai:

a. Perjanjian jual beli yang diatur dalam Pasal 1457-1540 BUku III KUH Perdata sejauh ketentuan-ketentuan itu relevan dengan anjak piutang. b. Pengalihan piutang atas nama yang diatur dalam Pasal 613 ayat (1) dan (2) Buku II KUH Perdata. Menruut ketentuan pasal tersebut, penyerahan piutang atas nama dialkukan dengan cessie, yaitu dengan akta autentik atau tidak autentik yang menyatakan pengalihan hak tagih kepada perusahaan anjak piutang disertai notifikasi kepada nasabah (debitur). Bersamaan dengan akta cessie piutang itu diserahkan.

c. Subrogasi yang diatur dalam Pasal 1400-1403 BUku III KUH Perdata. Penyerahan dengan cessie akan mengakibatkan adanya subrogasi, yaitu penggantian status kreditor lama (klien) oleh kreditor baru (persuaahan anjak piutang) terhadap nasabah (debitur).

Selain dari ketentuan-ketentuan dalam Buku II dan Buku III KUH Perdata yang relevan dengan anjak piutang, ada juga ketentuan-ketentuan dalam berbagai undang-undang di luar KUH Perdata yang mengatur aspek perdata anjak piutang. Undang-undang yang diamksud adalah sebagai berikut :

a. Undang-undang Nomor 40 Tahun 2007 tentang Perseroan Terbatas dan 
peraturan

pelaksanaannya.

Berlakunya undang-undang ini apabila anjak piutang itu mempunyai bentuk hukum Perseoran Terbatas.

b. Undang-Undang Nomor 25 Tahun 1992 tentang Perkoperasian dan peraturan pelaksanaannya. Berlakunya undang-undang ini apabila bentuk badan usaha perusahana anjak piutang tersebut adalah koperasi, sehingga di dalam pendirian dan kegiatannya juga harus mematuhi ketentuan-ketentuan yang diatur dalam undang-undang tersebut.

c. Undang-Undang Nomor 5 Tahun 1960 tentang Ketentuan-ketentuan Pokok Agraria dan peraturan pelaksanaannya. Ketentuanketentuan undang ini apabila perusahana anjak piutang mengadakan perjanjian mengenai hak atas tanah.

d. Undang-Undang Nomor 8 Tahun 1999 tentang Perlindungan Konsumen dan peraturan pelaksanaannya. Berlakunya undang-undang ini apabila perusahaan anjak piutang sebagai produsen melakukan pelanggaran atas kewajiban dan larangan undang-undang yang secara perdata merugikan konsumen.

\section{Segi Hukum Publik}

Sebagai usaha yang bergerak di bidang jasa pembiayaan, anjak piutang banyak menyangkut kepentingan public terutama yang bersifat administratif. Oleh karena itu, perundang-undangan yang bersifat public yang relevan berlaku pula pada anjak piutang. Perundang-undangan tersebut terdiri atas undnag-undang, peraturan pemerintah, keputusan presiden dan keputusan menteri.

\section{Undang-Undang di Bidang Hukum Publik}

Berbagai undang-undang di bidang administrasi negara yang menjadi sumber hukum utama anjak piutang adalah sebagai berikut :

a. Undang-Undang Nomor 3 Tahun 1982 tentang Wajib Daftar Perusahaan dan peraturan pelaksanaannya. Berlakunya undang-undang ini apabila perusahaan anjak piutang berurusan dengan pendaftaran perusahaan pada waktu pendirian, pendaftaran ulang dan pendaftaran likuidasi perusahaan.

b. Undang-Undang Nomor 7 Tahun 1992 jo Undang-Undang Nomor 10 Tahun 1998 tentang Perbankan dan peraturan pelaksanaannya. Berlakunya undang-undang ini apabila 
perusahaan anjak piutang

berkaitan dan berurusan dengan bank.

c. Undang-Undang Nomor 12 Tahun 1985, Undang-Undang Nomor 7 Tahun 1991, UndangUndang Nomor 8 Tahun 1991 dan peraturan pelaksanaannya, semuanya tentang Perpajakan. Berlakunya undang-undang ini karena perusahaan anjak piutang wajib membayar pajak bumi dan bangunan, penghasilan dan pertambahan nilai serta pajak jenis lainnya.

d. Undang-Undang Nomor 8 Tahun 1997 tentang Dokumen Perusahana dan peraturan pelaksanaannya. Berlakunya undnag-undang ini karena perusahana anjak piutang melakukan pembukuan perusahaan dan pemeliharaan dokumen perusahaan.

2. Peraturan tentang Lembaga Pembiayaan

Peraturan tentang lembaga pembiayaan yang mengatur anjak piutang antara lain adalah :

a. Keputusan Presiden Nomor 61 Tahun 1988 tentang Lembaga Pembiayaan. Didalamnya memuat tentang pengakuan bahwa anjak piutang sebagai salah satu bentuk usaha dari lembaga pembiayaan. Bentuk

hukum perusahaan anjak

piutang adalah Perseroan

Terbatas atau Koperasi, dan

dalam kegiatannya dilarang

menarik dana secara langsung

dari masyarakat dalam bentuk giro, deposito, tabungan dan surat sanggup bayar (promissory note).

b. Surat Keputusan Menteri Keuangan No. 1251/KMK.013/1988 tentang Ketentuan dan Tata Cara Pelaksanaan Lembaga Pembiayaan, yang kemudian diubah dan disempurnakan dengan Keputusan Menteri Keuangan Nomor 468 Tahun 1995. Dalam Keputusan Menteri Keuangan ini mengatur tentang kegiatan perusahaan anjak piutang, izin usaha, besaran modal, pembinaan dan pengawasan, serta sanksi apabila perusahaan anjak piutang melakukan kegiatan yang bertentangan dengan ketentuan-ketentuan dari Keputusan Menteri Keuangan tersebut.

\section{KESIMPULAN \\ Berdasarkan analisis deskriptif, pendekatan filosofis, dan pendekatan pedagogis yang dilakukan bahwa}


terdapat perbedaan aspek hukum pada perbankan dan lembaga anjak piutang yang berkaitan dengan mekanisme, pelaku, perkembangan perjanjian, distribusi risiko, cara mengatasi permasalahan di dalamnya, dan lain lain.

\section{SARAN DAN KETERBATASAN}

Saran dan keterbatasan dari hasil penelitian ini adalah:

1. Penelitian selanjutnya disarankan agar dapat memperbanyak dan menggunakan sumber

literature sehingga mendapatkan penjelasan yang lebih mendetail mengenai perbedaan perusahaan anjak piutang.

2. Penelitian selanjutnya disarankan agar dapat membandingkan lembaga keuangan lain selain perbankan sehingga hasil mampu menggambarkan beberapa aspek hukum di dalam lembaga keuangan.

3. Masyarakat membutuhkan literatur mengenai sektor keuangan agar kepercayaan dan kebutuhan terhadap SJK meningkat.

4. Dalam aspek hukum perlu adanya pembaharuan yang mendukung segala kegiatan SJK, khususnya hukum perbankan dan hukum perdata sebagai dasar hukum yang kuat agar SJK berkembang dan dapat menumbuhkan ekonomi.

\section{DAFTAR PUSTAKA}

Abubakar, Lastuti dan Handayani, Tri. (2017). Telaah Yuridis Terhadap Implementasi Prinsip Kehati-Hatian Bank Dalam Aktivitas Perbankan Indonesia. De Laga Lata Volume 2 Nomor 1 Januari-Juni pp 68-91

Handayani, L. dan Abubakar, L. (2017). Perkembangan Hukum Sektor Jasa Keuangan Dalam Upaya Percepatan Pertumbuhan Ekonomi Nasional. De Laga Lata, Volume 2 Nomor 2, Juli - Desember pp 418 - 443.

Idris, M. (2015). Perjanjian Kredit Perbankan Konvensional Dan Akad Pembiayaan Perbankan Syariah : Suatu Tinjauan Deskriptif Dalam Hukum Di Indonesia. Jurnal Komunikasi Hukum Volume 1, Nomor 1, Pebruari 2015, pp 24 42.

Ibrahim, J. (2004). Bank Sebagai Lembaga Intermediasi Dalam Hukum Positif.

Utomo, Bandung

Kasmir. (2012). Bank dan lembaga keuangan Lainnya. Jakarta : PT Raja Grafindo Persada.

Putri, H. O. dan Harahap, B. (2017). Eksistensi Anjak Piutang (Factoring) Dari Sisi Yuridis dan Ekonomis. Jurnal Repertorium Volume IV No. 1 Januari-Juni 2017 pp $36-44$.

Regar, R., William, A. A., dan Joula J. R. (2016). Analisis Pemberian Kredit Mikro Terhadap Peningkatan Nasabah Studi Pada 
PT. Bank Sulutgo Cabang Manado. Jurnal Administrasi Bisnis.

Wiwoho, Jamal. (2014). Peran Lembaga Keuangan Bank dan Lembaga
Keuangan Bukan Bank Dalam Memberikan Distribusi Keadilan Bagi Masyarakat. Jurnal MMH Jilid 43 No 1. 